\title{
Using of CFD software for setting the location of water stream micro turbines
}

\author{
Łukasz Borsuk ${ }^{1, a}$ \\ ${ }^{1}$ AGH University of Science and Technology, Faculty of Mining Surveying and Environmental Engineering, Department of Environmental \\ Management and Protection, Poland.
}

\begin{abstract}
The aim of this work was to estimate the efficiency of CFD software in calculating flow velocity magnitude in natural water streams. These kinds of estimations are essential for setting the locations of water stream micro turbines. These devices can be useful to provide electricity in areas remote from power generating facilities or as backup power supply in case of power grid failure. The analysed water stream has length of $100 \mathrm{~m}$ and its average slope was approximately $10 \%$. Water velocity varies in the range from $0.5 \mathrm{~m}^{3 *} \mathrm{~s}^{-1}$ to $5 \mathrm{~m}^{3 *} \mathrm{~s}^{-1}$. Additionally, the influence of ground roughness on the stream velocity was also an important factor. Results proved to be satisfactory. In the analysed stream, velocities were in a range which allows the proposed micro turbine to be effective. Calculation grid created by CFD software did not have many areas which may raise doubts. Also, the influence of changes in the ground roughness factor was noticeable. Preliminary CFD simulations allow to estimate where in the stream the micro turbine will be most efficient. On the other hand, despite these calculations, profitability and return on the investment still can be questionable.
\end{abstract}

\section{Introduction}

The aim of this work was to estimate the efficiency of Computational Fluid Dynamics (CFD) software in calculating flow velocity magnitude in natural water streams. This task is complicated because the river bed is not the only factor that should be taken into consideration. Also ground roughness coefficient and yearly changes in river flow are very important factors in such estimations.

This type of calculation can be used as a support for decisions concerning the placement of water stream micro turbines. Additionally, information about water stream velocity is crucial to estimate the optimal type of turbine for a particular part of the river. Also, as the optimal placement of the turbine determines how much power that turbine can generate, it is possible to approximate potential benefits from the investment.

Micro water stream turbines can have a variety of uses, from providing power to households remote from the power grid, through alternative power supply in case of blackout accidents, up to supplying power in the tourism industry, e.g. on a camping near the river side. Additional aim of this work was to estimate how profitable this type of device can be.

CFD Software is successfully used as a help for designing turbines. But in that kind of usage, the influence of environment is not treated with sufficient attention. In literature [1-3], uneven river bed surface is an overlooked issue. Also turbine models are created with flat ground and steady stream flow conditions in mind. This is a result of problems with creating an accurate Digital Elevation Model of the river bed ground level. But according to the latest literature [4-6], it seems reasonable to think about development in that direction. New sonar devices and advanced methods of laser scanning can be used with success to create a sustainable and trustworthy ground model of the river bed, as exemplified in figure 1 .

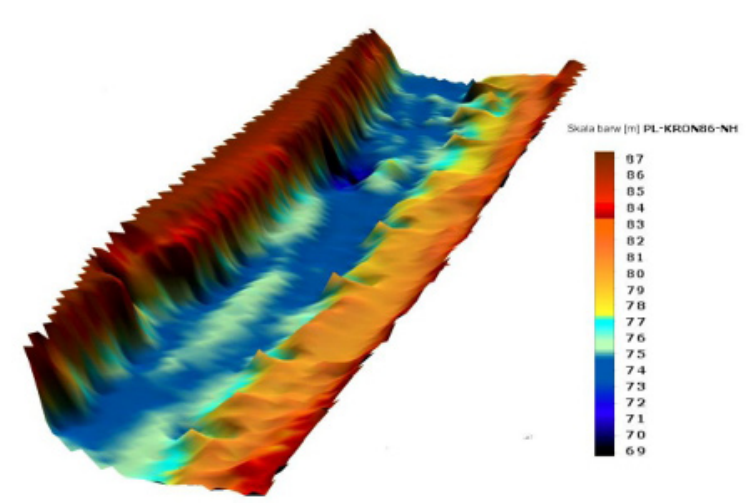

Figure 1. River bed model of flooded area, source: [4]

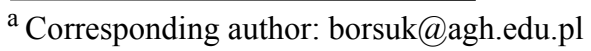


Assuming that Digital Elevation Model will be available for reasonable price, it is important to answer the following question: will the CFD model based on this type of data prove a reliable solution to engineering problems?

\section{Materials and methods}

\subsection{River bed ground level}

AutoCAD Civil 3D was used to create a river bed model necessary for this analysis. The terrain model is $100 \mathrm{~m}$ long and its width varies from $1.5 \mathrm{~m}$ to $3 \mathrm{~m}$. River bed was generated from over 5000 points using surface modelling tools. Although those tools are designed to calculate land masses, they also can be applied in this unorthodox way. River bed is irregular: there are areas of shallow water, especially upstream. Additionally, near the river curves, there are also deeper areas of the river. This part of watercourse was not based on any existing example; it is only a hypothetic situation created for the purpose of this study. On the length of $100 \mathrm{~m}$ the average slope of the ground level was around $10 \%$. Additionally, to increase realism and to test the software in more difficult conditions, river bed curves three times. This situation and the complete river bed is shown in figure 2.

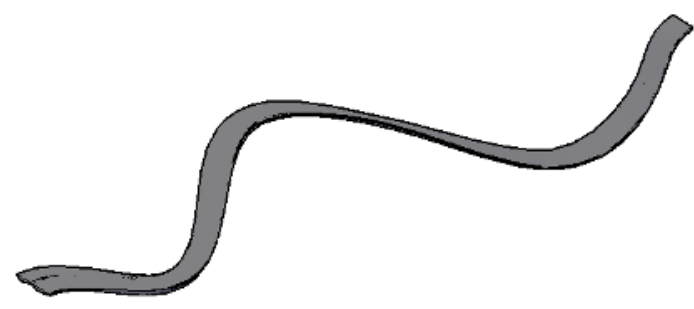

Figure 2. River bed model, source: own elaboration.

\subsection{Variable flow velocity}

The change of velocity with time is an important parameter which has to be considered to perform a reliable analysis. Calculations were run using three different variants. First of them, according to the existing studies [7], was low-flow which can occur during light rain, so that velocity does not exceed $0.5 \mathrm{~m}^{3 *} \mathrm{~s}^{-1}$. Second variant is close to average flow rate from multi-year equal to $2 \mathrm{~m}^{3 *} \mathrm{~s}^{-1}$. Last case concerns the flows that can be measured in months with highest amount of rainfall and it is $5 \mathrm{~m}^{3 *} \mathrm{~s}^{-1}$. These flow velocities were often measured in Polish rivers from years 1965 to 2015 [7]. An additional assumption is that this watercourse is classified as a small lowland river.

\subsection{Ground roughness coefficient}

Ground roughness was also taken into consideration. The Manning's n values were established according to classic literature [8]. For that, three variable conditions were created. The first one was assumed for clean river bed without serious disturbances and the roughness was equal to $n=0.025$. In the second variant, calculations was run for $n=0.05$, as this value is characteristic for heavily overgrown water streams. The third case was extreme: river had significant amount of water plants and additional roughness was added by fallen trees and rocks. For this condition Manning's coefficient was $\mathrm{n}=0.150$. The reason for presenting this wide variety of ground types was to assess the sensitivity of software to roughness. If the results were similar, it would mean that Autodesk Simulation CFD underestimates the influence of this factor on the calculations.

\subsection{Software}

According to paragraph 2.1., elevation model of river bed was created mainly by the AutoCAD Civil 3D software. All the calculations inside the model were run in Autodesk Simulation CFD. Both of them were created by the same company so cooperation between them and data exchange does not generate errors. Autodesk Simulation CFD has tools which can be used to implement various boundary conditions such as flow rates, roughness, gravity force etc. Additionally, surface models imported from Autodesk Civil 3D were processed to calculating mesh by automatic scripts. It gives an opportunity to check quality of algorithms used by software in these cases. Unfortunately, one of the decisive defects of the Autodesk Simulation CFD is lack of tools that can be used to perform multiphase calculations. Therefore, influence of atmosphere (for example wind) must be omitted.

\section{Results}

\subsection{Results of analysis for different velocities}

Results for the different velocity conditions are shown in figures 3-5. Water volume in which velocity exceeds the level mentioned in the caption was highlighted. Also it is important to remember that Manning's roughness coefficient for figures $3-5$ was equal $n=0.05$. Turbine [9] used to calculate generated power starts working at velocity of $1 \mathrm{~m}^{*} \mathrm{~s}^{-1}$ and it reaches optimal power at $4 \mathrm{~m}^{*} \mathrm{~s}^{-1}$.

According to figure 3, even with the lowest flow rate in this particular river bed it is possible to find places in which a turbine will work properly. Unfortunately, the generated power will be low because flow speed is barely enough to start the turbine. In this case, the amount of electric power generated by this micro turbine can be estimated at $10 \mathrm{~W}$. 


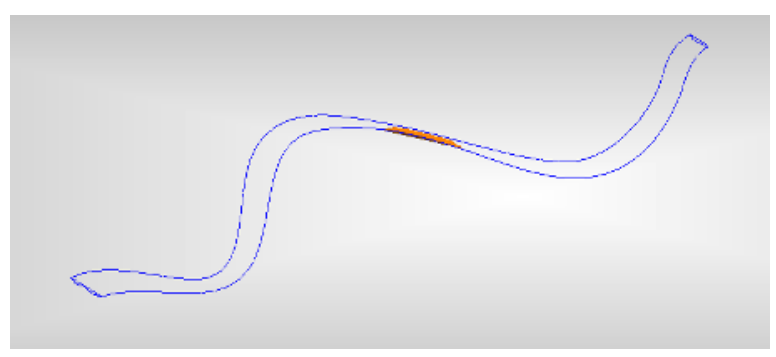

Figure 3. Surface of area in which velocity is higher than 1 $\mathrm{m}^{*} \mathrm{~s}^{-1}$ for flow rate of $0.5 \mathrm{~m}^{3 *} \mathrm{~s}^{-1}$, source: own elaboration.

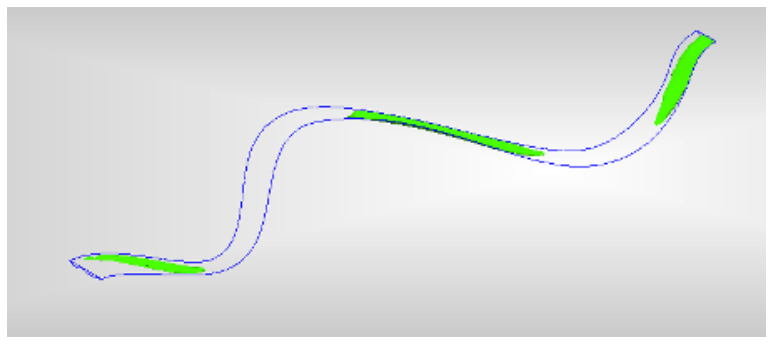

Figure 4. Surface of area in which velocity is higher than $2,5 \mathrm{~m}^{*} \mathrm{~s}^{-1}$ for flow rate of $2 \mathrm{~m}^{3 *} \mathrm{~s}^{-1}$, source: own elaboration.

In this case, velocities highlighted in figure 4 are high enough to reach $50 \%$ of turbine efficiency; it can give approximately $60 \mathrm{~W}$ of power. Unfortunately, there is no area in the river in which a turbine can work in optimal way.

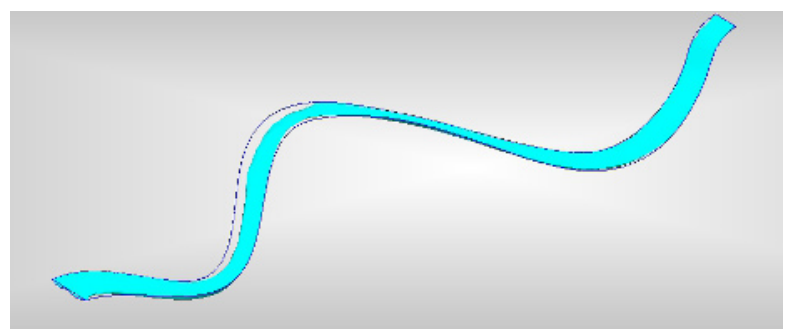

Figure 5. Surface of area in which velocity is higher than $4 \mathrm{~m}^{*} \mathrm{~s}^{-1}$ for flow rate of $5 \mathrm{~m}^{3 *} \mathrm{~s}^{-1}$, source: own elaboration.

The last case shows that if the water level is high enough and stream velocity is significant, a turbine will have optimal conditions for work almost in any area of the river. Power generated with these variables can approximate to $100 \mathrm{~W}$.

\subsection{Analysis of return on the investment}

According to the obtained results, return on the investment is unclear. Purchase cost of the considered turbine [9] is near 2200\$. Assuming an extremely optimistic scenario in which the average flow is near $2.5 \mathrm{~m}^{3 *} \mathrm{~s}^{-1}$ for the whole year and turbine works without any conservation breaks, the generated power will be approximately $525 \mathrm{kWh}$. Actual market price of electric power in Poland is at the level of $0,16 \$$ for $1 \mathrm{kWh}$. Taking into account the presented data, the investment will fully pay off in about 26 years.
And if the scenario is be more realistic, for example there are gaps in worktime or usage of the turbine generates some repair costs, this kind of investment seems to be unprofitable. Additionally, even as an alternative source of power supply it is barely useful. The generated power of $60 \mathrm{~W}$ will not be sufficient to supply most of the common electrical devices. In this scenario, it will be necessary to invest in more than one turbine or some kind of batteries which will lead to further increase in the investment cost.

\subsection{Quality of automatically generated mesh}

Automatic generation of computing mesh allows to optimize the time necessary for running calculations. Unfortunately, it seems that this algorithm does not generate mesh dense enough to show exactly what is happening with the velocities on the border between fluid and ground surface. In figure 6 it is possible to observe that this area is treated without necessary attention. In commercial analysis, density of computing mesh near the ground level should be noticeably increased. In addition to this, size of edge folds shown in figure 6 will significantly decrease.

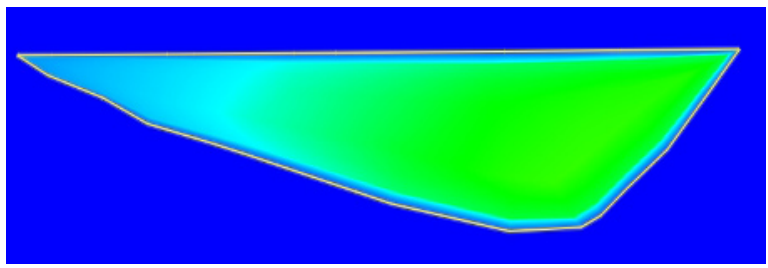

Figure 6. Cross-section example, source: own elaboration.

\subsection{Influence of Manning's roughness coefficient on the results}

Another element which can influence the quality and reliability of the analysis is the impact of ground roughness on the results. This factor was noticeable in all cases of the analysis. Migration of the highest velocity field in the stream to the middle of the river bed increases significantly with $\mathrm{n}$ value. Unfortunately, according to the previous paragraph and to figure 6 it is impossible to track specific changes near the edges of the analysed stream.

\section{Discussion}

Method shown in the presented analysis seems to be promising. If the geodetic data, like those in figure 1 and literature [4-6], are more available, there will be an opportunity to perform this type of analysis more often. Consequently, the results of this kind of calculations will be improved. Also, it seems that it is possible to perform this type of analysis not only on even surfaces but also on rough terrain which constitutes a development of concepts shown in the literature [1-3]. Results for the different velocities do not raise crucial doubts. But the usage of micro turbines in practice is not as obvious as it seems. On the one hand, it was shown 
that if the flow magnitude is high enough, it is possible to create optimal performance conditions for water stream micro turbines. On the other hand, this type of devices generates too low power to be considered as a reliable source of electric energy. Also, full return on the investment takes 26 years (in perfect conditions), which may raise doubts about the profitability of the investment.

\section{Conclusions}

Autodesk Simulation CFD can be used to estimate stream velocity in river bed with complicated ground level. In the simulation influence of flow change and Manning's roughness coefficient is noticeable. Also, use of denser computing mesh and more reliable geodetic data will significantly increase the quality of analysis. However, profit from the usage of water stream micro turbines is unclear. Generated power may raise doubts about profitability of the investment.

\section{References}

1. S.C. Tatum , C.H. Frost , M. Allmark, D.M. O’Doherty, A. Mason-Jones , P.W. Prickett, R.I. Grosvenor, C.B. Byrne , T. O’Doherty. Wavecurrent interaction effects on tidal stream turbine performance and loading characteristics, (International Journal of Marine Energy, 2015)

2. M.I. Shahidul, S.S Syed Tarmizi, Abdullah Yassin, Al Khalid Othman, Hushairi Zen, Ting Ching Hung, Lee Man Djun. Modeling the Energy Extraction from In-stream Water by Multi Stage Blade System of Cross Flow Micro Hydro Turbine, (Procedia Engineering Volume 105, 2015, Pages 488-494)

3. Taimoor Asim, Rakesh Mishra, Kuldip Ubbi, Karina Zala. Computational Fluid Dynamics Based Optimal Design of Vertical Axis Marine Current Turbines. (Procedia CIRP Volume 11, 2013, Pages 323-327)

4. Laskowska K., Lesiak M., Rola pomiarów batymetrycznych $\quad w \quad$ bezpieczeństwie przeciwpowodziowym (XXIX Seminarium Kół Studenckich Wydziału Inżynierii Lądowej I Geodezji)

5. Łubczonek J., Zaniewicz G., Modeling and visualization of digital terrain model and sea bottom for port security geoinformatic system, (Archiwum Fotogrametrii, Kartografii i Teledetekcji Vol. 24, 2012, s. 187 - 198)

6. Gołuch P., Dombek A., Kapłon J., Evaluation of data accuracy obtained from bathymetric measurement using fish finder Lawrence LMS-527C DF iGPS, (Archiwum Fotogrametrii, Kartografii i Teledetekcji, Vol. 21, 2010, s. 109-118)

7. Kanclerz J., Murat-Błażejewska S., Sojka M., Zmienność przeplywów małej rzeki nizinnej, (Zeszyty problemowe postępów nauk rolniczych 2008 z. 528: 71-78)

8. Chow V.T., Open-Channel Hydraulics, (Mc Graw Hill Book, New York, 1959)

9. http://www.seamap.com/products/ampair/ampairuw100/ (Access

17.04.2016) 